\title{
Description and relationships of Otothyropsis marapoama, a new genus and species of Hypoptopomatine catfish (Siluriformes: Loricariidae) from rio Tietê basin, southeastern Brazil
}

\author{
Alexandre C. Ribeiro*,**, Murilo Carvalho*, and Alex L. A. Melo*,***
}

Otothyropsis marapoama, a new genus and species, is described based on specimens recently collected in a headwater stream of the middle stretch of the rio Tietê, a river from the upper rio Paraná basin in southeastern Brazil. The new taxon belongs to a clade also encompassing the genera Schizolecis, Otothyris and Pseudotothyris. Otothyropsis marapoama is hypothesized to be the sister-group of Pseudotothyris and Otothyris based mainly on the presence of several derived characters of the swimbladder capsule and associated bones. Several paedomorphic characters shared by Pseudotothyris and Otothyris and their significance for the phylogenetic position of the new genus are discussed.

Otothyropsis marapoama, novo gênero e espécie, é descrito baseado em espécimes recentemente coletados em um riacho de cabeceira da porção media do rio Tietê, um rio da bacia do alto rio Paraná no sudeste do Brasil. O novo táxon pertence a um clado que inclui também os gêneros Schizolecis, Otothyris e Pseudotothyris. Otothyropsis marapoama é considerado o grupo-irmão de Pseudotothyris e Otothyris baseado principalmente na presença de vários caracteres derivados da cápsula da bexiga natatória e ossos associados. Vários caracteres pedomórficos compartilhados por Pseudotothyris e Otothyris e seu significado filogenético para a posição deste novo gênero são discutidos.

Key words: Otothyrini, Systematics, Paedomorphic characters.

\section{Introduction}

The South American subfamily Hypoptopomatinae is a monophyletic unit of the Loricariidae arranged in two tribes, the Otothyrini and Hypoptopomatini, encompassing up to 70 species in 16 genera (Schaefer, 2003). The most comprehensive phylogenetic scheme available for Hypoptopomatinae is that proposed by Schaefer (1998), in which each tribe was considered monophyletic. Within the Otothyrini, one of the stronger clades includes the genera Schizolecis Britski \& Garavello, 1984, Pseudotothyris Britski \& Garavello, 1984 and Otothyris Myers, 1927, which share unique specializations of the cranium associated with an enlarged swimbladder capsule. The degree of development of the swimbladder capsule in these genera was not found in any other member of the Otothyrini (Schaefer, 1998).
Recent collecting efforts in headwater streams of the middle stretch of the rio Tietê, a tributary of the upper Paraná basin, led to the discovery of an undescribed species of the tribe Otothyrini, which also shares a highly developed swimbladder capsule. The inclusion of this new taxon in Schaefer's (1998) phylogenetic scheme led us to include it in the clade containing the genera Schizolecis, Pseudotothyris and Otothyris. A more detailed analysis reveals a close relationship of the new taxon with the clade that includes Otothyris and Pseudotothyris.

In this paper, describe this recently discovered catfish and place it into a new genus. We also provide the foundation for this taxonomic decision based on the inclusion of the new taxon in the phylogenetic framework of the subfamily Hypoptopomatinae proposed by Schaefer (1998).

The discovery of this new taxon exemplifies the paucity of

\footnotetext{
*Laboratório de Ictiologia de Ribeirão Preto (LIRP), Depto. Biologia, FFCLRP-USP, Av. Bandeirantes, 3900, 14040-901 Ribeirão Preto, SP, Brazil.

**Depto. Zoologia, Instituto de Biociências, Universidade Estadual Paulista Júlio de Mesquita Filho (UNESP-Botucatu), Caixa Postal 510, Botucatu, SP, Brazil.

***Depto.Ciências Biológicas, Universidade de Franca (UNIFRAN), Av. Dr. Armando Salles de Oliveira, 201, Caixa Postal 82, 14404-600 Franca, SP, Brazil.
} 


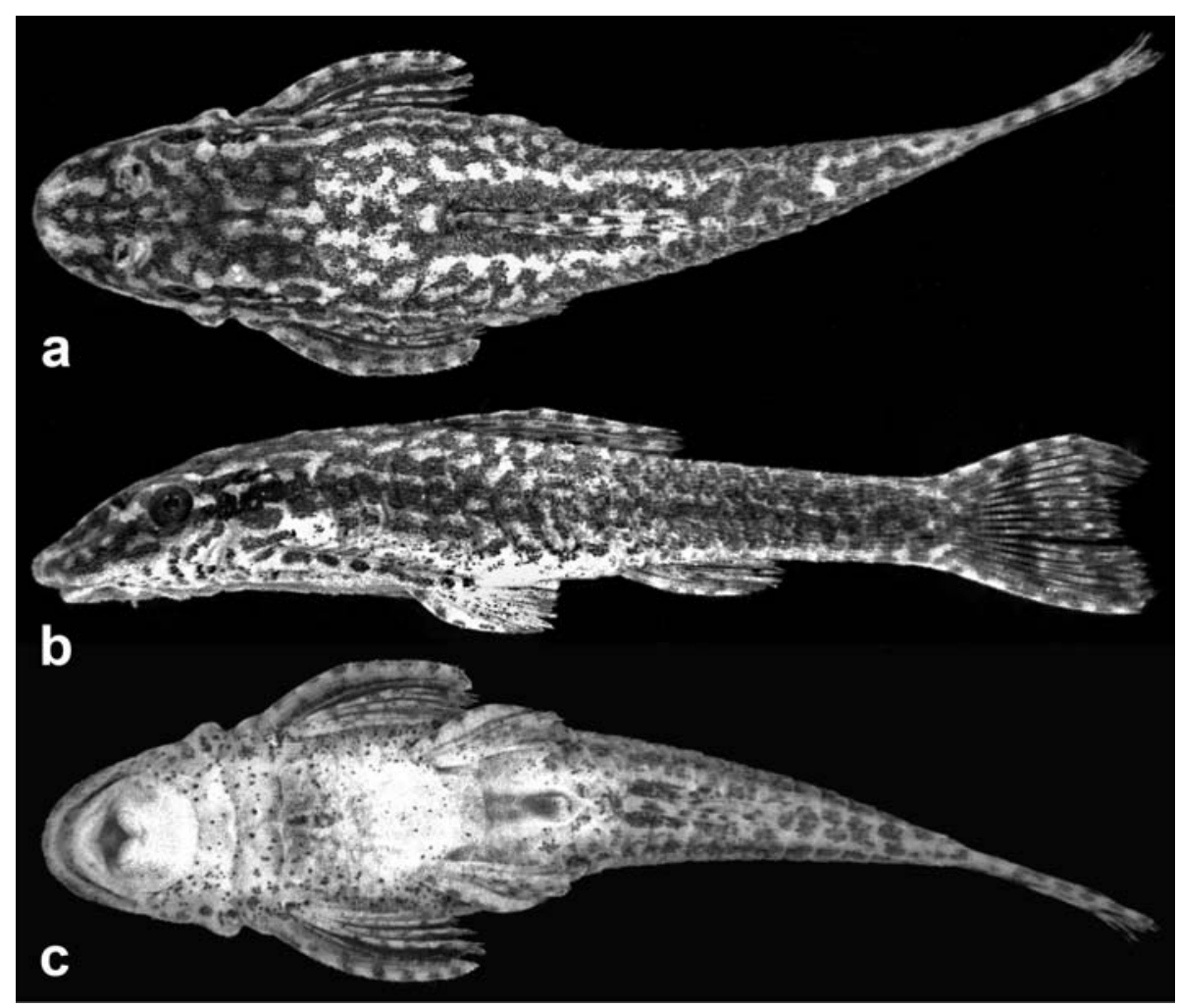

Fig. 1. Otothyropsis marapoama, holotype, LIRP 5640, $38.5 \mathrm{~mm}$ SL. Brazil, São Paulo, rio Tietê basin, Município de Marapoama, ribeirão Cubatão, off the road between Marapoara and Elisiário (21 $\left.{ }^{\circ} 11^{\prime} 35^{\prime \prime} \mathrm{S} 49^{\circ} 07^{\prime} 22^{\prime \prime} \mathrm{W}\right)$. Dorsal (a), lateral (b), and ventral (c) views.

knowledge of alpha diversity in the neotropics, especially on groups of small-sized fishes such as those of the Hypoptopomatinae. It also illustrates the risk of extinction of taxa that have not yet been described. In fact, the region where this new species was sampled is one of the most heavily impacted by anthropogenic activities in Brazil, and the lack of previous records of such a distinctive fish suggests a high degree of endemism and, consequently, a high degree of vulnerability.

\section{Material and Methods}

Morphological measurements were made point-to-point, to the nearest $0.1 \mathrm{~mm}$ with digital calipers. Methodology and terminology for measurements follow Boeseman (1968: 26-27, fig. 5) with modifications suggested by Armbruster \& Page (1996). Two additional measurements were included: preanal length (taken from snout tip to the anal-fin origin) and maxillary barbel length (taken from barbel tip to its insertion on oral disk). Plate counts and nomenclature follow the schemes of serial homology proposed by Schaefer (1997). Counts follow Bockmann \& Ribeiro (2003), but the following additional count was included: lateral abdominal plates (number of abdominal plates in the lateral abdominal series between the scapular bridge and pelvic-fin origin) (Britski \& Garavello, 1984). Vertebral counts included all vertebrae (including the first five vertebrae modified into Weberian apparatus), with the compound caudal centrum (PU1+U1) (Lundberg \& Baskin,
1969) counted as one element. All morphometric and meristic data, including premaxillary and dentary tooth counts, were taken from the left side of the specimens.

Morphometric data were expressed as percent of standard length (SL), except subunits of the cephalic region which were expressed in percent of head length. Anal width was also expressed as percent of cleithral width.

Plate counts were performed on 8 specimens stained in alizarin red solution (Taylor \& Van Dyke, 1985) because limits of plates are difficult to identify in unprepared material. Osteological examination was made on specimens cleared and double-stained according to the procedure of Taylor \& Van Dyke (1985).

Materials examined are from LIRP (Laboratório de Ictiologia de Ribeirão Preto, Universidade de São Paulo, Ribeirão Preto, Brazil), MZUSP (Museu de Zoologia da Universidade de São Paulo, São Paulo, Brazil), MNRJ (Museu Nacional do Rio de Janeiro, Rio de Janeiro, Brazil), MCP (Museu de Ciências e Tecnologia da Pontifícia Universidade Católica do Rio Grande do Sul, Porto Alegre, Brazil), and DZSJRP (Coleção de Peixes do Departamento de Zoologia e Botânica do Instituto de Biociências, Letras e Ciências Exatas, Universidade Estadual Paulista, São José do Rio Preto, Brazil).

Phylogenetic analyses were performed using the character matrix published by Schaefer (1998), including outgroup data provided in that study, with the addition of the new species. The analysis was performed using PAUP version 3.1.1 (Swofford, 1993). We used the stepwise addition option 
of the heuristic search algorithm, with a random addition sequence and 10 replications. The optimization criterion was ACCTRAN.

Abbreviations of bones in Figs. 3-9 are: $\mathrm{AA}=$ compound anguloarticular; $\mathrm{AH}=$ anterohyal; $\mathrm{AP}=$ abdominal plates; $\mathrm{BB}$ = basibranchial; $\mathrm{BPT}=$ basipterygium $; \mathrm{BR}=$ branchiostegal; $\mathrm{CB}=$ ceratobranchial; $\mathrm{CBF}=$ ceratobranchial flange; $\mathrm{CL}=$ cleithrum; $\mathrm{CO}=$ coracoid; $\mathrm{CP} 1-\mathrm{CP} 2=$ subocular cheek plates 1 and 2; $\mathrm{EB}=$ epibranchial; $\mathrm{EB} 4=$ epibranchial 4; $\mathrm{EBF}=$ epibranchial flange; $\mathrm{F}=$ frontal; $\mathrm{HB}=$ hypobranchial; $\mathrm{HH}$ =hypohyal; $\mathrm{HM}=$ hyomandibula; $\mathrm{IO} 1-\mathrm{IO} 5=$ infraorbitals; LAP $=$ lateral abdominal plates; $\mathrm{LE}=$ lateral ethmoid; $\mathrm{LPT}=$ lateropterygium; $\mathrm{ME}=$ mesethmoid; $\mathrm{MPT}=$ metapterygoid; $\mathrm{MX}=$ maxilla; $\mathrm{N}=$ nasal $; \mathrm{OP}=$ opercle $; \mathrm{OS}=$ orbitosphenoid; $\mathrm{PAL}=$ palatine $; \mathrm{PB}=$ infra-pharyngobranchial; $\mathrm{PB} 3-\mathrm{PB} 4=$ infra-pharyngobranchial 3 and $4 ; \mathrm{PF}=$ prefrontal plate; $\mathrm{PH}=$ posterohyal; $\mathrm{PMX}=$ premaxilla; $\mathrm{PN}=$ pre-nasal plates $; \mathrm{PO}=$ prootic; PR1-PR4 postrostral plates; PS = parasphenoid; PTS = pterosphenoid; PT-SC $=$ compound pterotic-supracleithrumpost-temporal; $\mathrm{Q}=$ quadrate; $\mathrm{R}=$ rostral plate; $\mathrm{SOC}=$ supraoccipital; $\mathrm{SP}=$ sphenotic $; \mathrm{UH}=$ urohyal; $\mathrm{V}=$ vomer.

\section{Results}

\section{Otothyropsis, new genus}

Type species: Otothyropsis marapoama by original designation.

Diagnosis. The clade that includes Otothyropsis, Otothyris and Pseudotothyris differs from the remaining genera of the Hypoptopomatinae by having an elongate posterior extension of the pterotic-supracleithrum which forms the dorsal margin of an enlarged lateral opening of the swimbladder capsule ( $v s$. quadrangular in shape and not extending posteriorly to form the dorsal margin of swimbladder capsule), and by having the supraoccipital forming the dorsal wall of the swimbladder capsule ( $v s$. supraoccipital does not contribute to dorsal wall of swimbladder capsule) (derived states of characters 8 and 12 of Schaefer, 1998). Otothyropsis, however, differs from Pseudotothyris and Otothyris by having enlarged odontodes on the dorsal and ventral margins of the snout (vs. enlarged odontodes only on the dorsal margin); by lacking conspicuous crests of enlarged odontodes on the tip of supraoccipital and pterotic-supracleithrum in adults ( $v s$. adults with well-developed crests), and by having the abdomen completely plated in adults (vs. adults with abdominal platelets reduced, sometimes restricted to lateral abdominal plate series).

The following characters were considered autapomorphic in our reanalysis of Schaefer's (1998) phylogenetic framework of the Hypoptopomatinae, and phylogenetically diagnoses the new genus Otothyropsis: presence of a single median rostral plate; presence of enlarged odontodes in both dorsal and ventral snout margins (derived conditions of characters, 34 and 39 of Schaefer's, 1998 phylogeny); and presence of the ocular diverticulum (reversal of character 42 of
Schaefer's, 1998 phylogeny). None of these characters, however, are exclusive to Otothyropsis, being considered homoplasies according to the parsimony analysis.

Etymology. The first part of the name is from Greek (otos = ear and thyris $=$ window) and is in reference to the Hypoptopomatinae genus Otothyris, to which the new taxon is closely related. The second part is from the Greek (opsis = relating to sight and appearance); hence, resembling a hypoptopomatine fish. Gender: feminine.

\section{Otothyropsis marapoama, new species}

Fig.1

Holotype: LIRP 5640, 38.5 mm SL, Brazil, São Paulo, rio Tietê basin, Município de Marapoama, ribeirão Cubatão, road between Marapoama and Elisiário $\left(21^{\circ} 11^{\prime} 35^{\prime \prime} \mathrm{S} 49^{\circ} 07^{\prime} 22^{\prime \prime} \mathrm{W}\right)$ (Fig.2), 10 Feb 2003; A. L. A. Melo.

Paratypes: LIRP 4621, 3, 27.6-32.3 mm SL (1,27.6 mm SL c\&s), collected with holotype; MZUSP 87892, 1, $28.6 \mathrm{~mm}$ SL, collected at type locality, 14 Jul 2004, A. L. A. Melo, A. C. Ribeiro, M. Carvalho \& A. K. Takako; LIRP 5641, 20, 18.0-29.0 mm SL (4, 19.8-29.0 mm SL c\&s; 4 stained with alizarin red solution); MZUSP 87893, 10, 18.7-23.0 mm SL, MCP 38303, 10, 18.2-22.8 mm SL and DZSJRP 7887, 8, 19.3-21.9 mm SL, Brazil, São Paulo, rio Tietê basin, Município de Catanduva, Sítio Cubatão, córrego Cubatão (21ํ14'53.4"S 4901'18.8"W), 14 Jul 2004, A. L. A. Melo, A. C. Ribeiro, M. Carvalho \& A. K. Takako.

Diagnosis. As for genus.

Description. Morphometrics and meristics given in Tables 1 and 2 respectively. Dorsal profile of body gently arched from snout tip to dorsal-fin origin; slightly concave to straight at dorsal-fin base; straight from end of dorsal-fin base to cau-

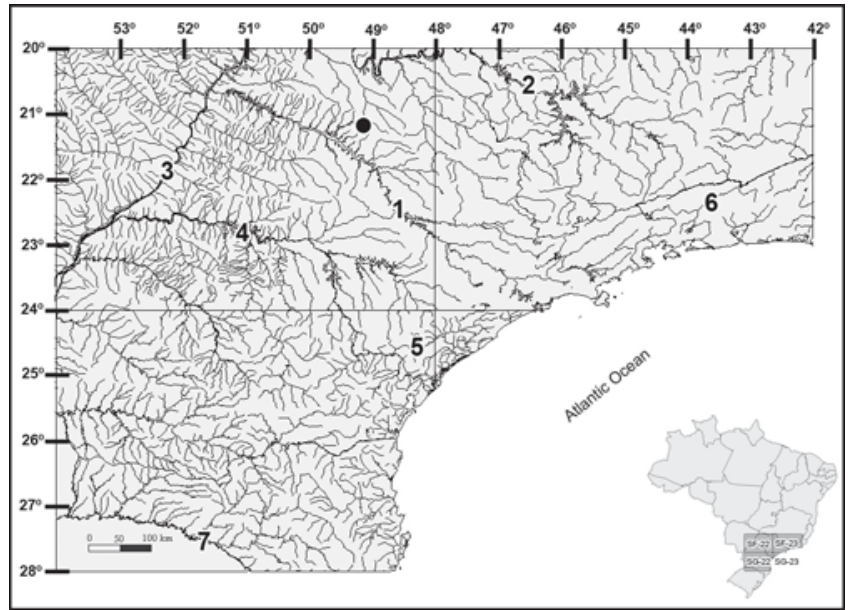

Fig. 2. Southeastern Brazil showing type-locality of Otothyropsis marapoama in the middle stretch of the rio Tietê basin (1: rio Tietê; 2: rio Grande; 3: rio Paraná; 4: rio Paranapanema; 5: rio Ribeira de Iguape; 6: rio Paraíba do Sul). 
dal-fin origin. Ventral profile of body straight to slightly concave from snout tip to base of pectoral fin; straight from that point to anal-fin origin, slightly concave at anal-fin base, and then straight from end of anal-fin base to caudal-fin base. Greatest body depth at dorsal-fin origin. Least body depth at caudal peduncle. Greatest body width at opercular or cleithral regions. Trunk gradually tapering to caudal-fin base. Trunk and caudal peduncle rounded (smaller individuals) to slightly square (in the holotype, the larger specimen with $35.8 \mathrm{~mm} \mathrm{SL}$ ) in cross section, trunk slightly flattened at base of dorsal and pectoral fins and laterally compressed caudally. Body progressively narrowing caudally from cleithrum. Head wide and rounded anteriorly. Interorbital region flat to slightly convex, with latter margin slightly elevated. Snout straight at mid-line and concave in the region anterior to nares in both sides of head. Eye laterally placed. Superior margin of orbit conspicuously elevated, forming a ridge around orbital margin. Region of pterotic-supracleithrum posterior to orbital margin slightly depressed. Lateral wall of pterotic pierced by enlarged fenestrae, which are visible externally (Fig. 3).

Body surface without well-developed crests. Body and abdomen entirely covered by plates, except for small ventral surface in front of anus, region overlying opening of swim bladder capsule, and around pectoral, pelvic, and anal-fin insertions. Rostral plates well-developed and projecting ventrally over the ventral margin of snout (Fig. 3b). Head and body plates covered with pointed odontodes, mostly uniform in size and distribution, not arranged in conspicuous rows. Odontodes from dorsal and ventral surface of snout slightly larger than remaining ones. Odontodes at tip of supraoccipital and com-

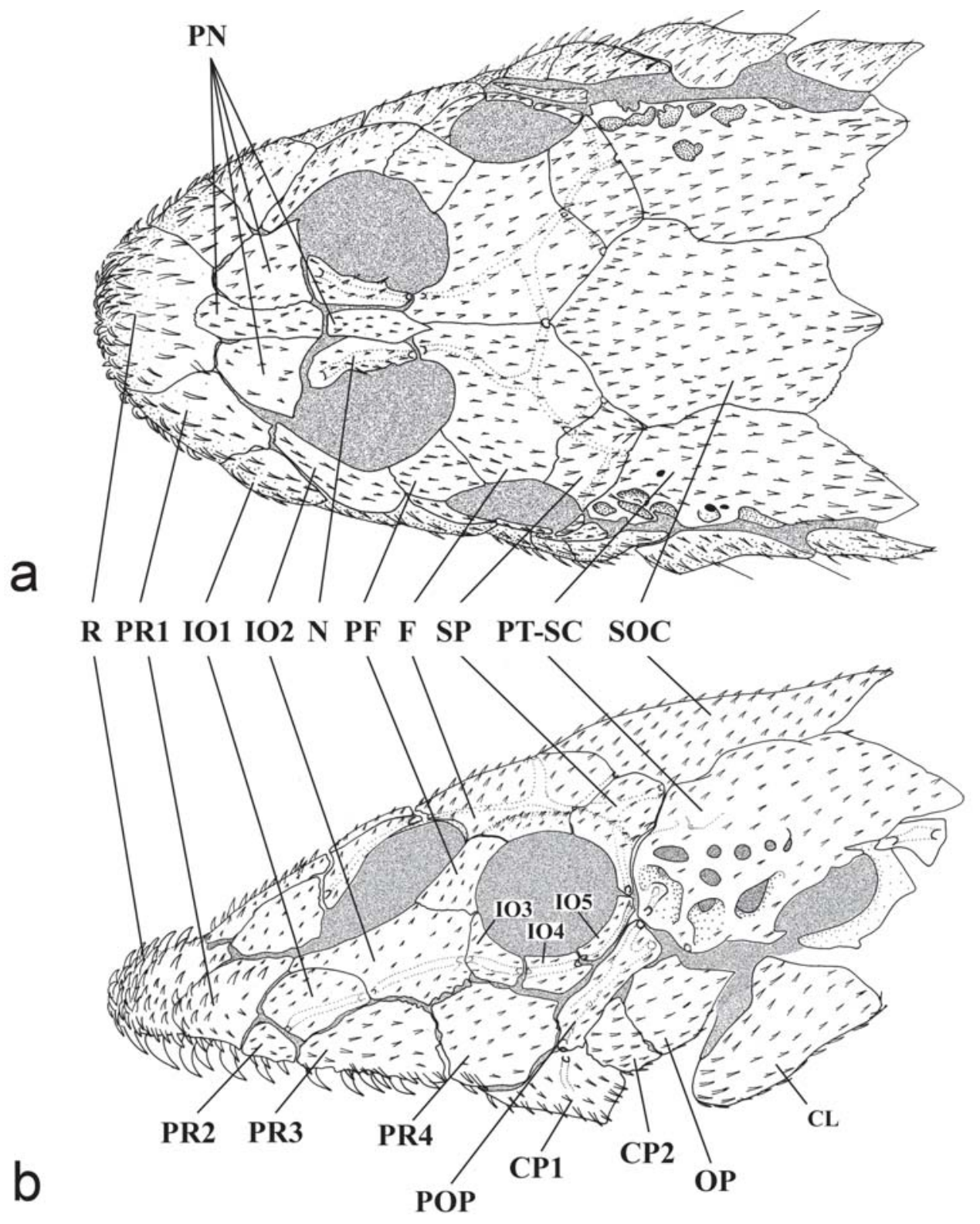

Fig. 3. Skull of Otothyropsis marapoama, paratype, LIRP 5641, $29.0 \mathrm{~mm}$ SL, a) dorsal view; b) lateral view. 
Table 1. Descriptive morphometrics of Otothyropsis marapoama. Values are given for the holotype (separately) and 14 paratypes. $\mathrm{Hol}=$ Holotype; $\mathrm{SD}=$ Standard Deviation .

\begin{tabular}{lccccc}
\hline Character & Hol & \multicolumn{7}{c}{ Minimum Maximum Mean } & SD \\
\hline Standard length (mm) & 38.5 & 19.6 & 38.5 & 25.6 & 5.2 \\
Percents of standard length & & & & & \\
$\quad$ Predorsal length & 46.0 & 44.4 & 50.3 & 46.8 & 1.9 \\
Preanal length & 61.8 & 58.4 & 64.1 & 61.6 & 1.8 \\
Head length & 32.4 & 30.2 & 38.2 & 35.5 & 2.3 \\
Cleithral width & 23.9 & 21.8 & 25.3 & 23.7 & 1.0 \\
Dorsal-fin spine length & 25.7 & 22.7 & 33.3 & 26.3 & 2.5 \\
Folded dorsal-fin length & 25.7 & 25.4 & 33.3 & 27.7 & 2.1 \\
Base of dorsal-fin length & 15.3 & 11.2 & 17.6 & 14.6 & 1.8 \\
Thorax length & 18.1 & 14.5 & 20.7 & 17.9 & 1.7 \\
Pectoral-fin spine length & 23.5 & 23.5 & 31.1 & 27.6 & 1.9 \\
Abdomen length & 14.1 & 10.4 & 14.9 & 13.4 & 1.2 \\
Pelvic-fin spine length & 12.8 & 12.8 & 19.0 & 16.2 & 1.8 \\
Postanal length & 34.5 & 32.3 & 40.3 & 35.8 & 2.3 \\
Caudal-peduncle depth & 9.2 & 9.0 & 11.0 & 9.8 & 0.5 \\
Anal width & 13.3 & 9.6 & 14.0 & 11.8 & 1.3 \\
Snout-opercle length & 23.5 & 21.9 & 26.6 & 24.1 & 1.2 \\
Percents of head length & & & & & \\
Head width & 72.8 & 6.7 & 12.5 & 9.1 & 1.6 \\
Head depth & 44.2 & 51.2 & 79.3 & 59.7 & 7.6 \\
Snout length & 50.3 & 40.0 & 54.8 & 44.5 & 3.5 \\
Interorbital length & 46.2 & 46.5 & 57.2 & 50.4 & 3.0 \\
Orbital diameter & 15.5 & 34.6 & 47.9 & 39.5 & 4.0 \\
Barbel length & 8.6 & 13.6 & 19.9 & 15.4 & 1.7 \\
Percents of cleithral width & & & & & \\
Anal width & 55.4 & 43.2 & 57.0 & 49.5 & 4.4 \\
\hline & & & & & \\
& & & &
\end{tabular}

pound petrotic-supracleithrum-posttemporal slightly larger than remaining odontodes of head, but not forming conspicuous crests (Fig. 3). Pectoral girdle almost completely exposed, except for small median area covered by skin (Fig. 4a). Pelvic girdle with solid basipterygium anteriorly (Fig. 4b).
Tip of adpressed pectoral fin reaching to middle of pelvic fin, with posterior margin slightly rounded. Well-developed slit present posterodorsally to pectoral insertion. Tip of adpressed pelvic fin reaching anus. Pelvic-fin spine smaller than branched rays and supporting medially projected odontodes. Dorsal-fin origin at vertical behind end of pelvicfin base. Dorsal-fin spinelet small, with dorsal-fin locking mechanism non-functional. Adipose fin absent. Ventral caudal-fin lobe slightly longer than dorsal lobe.

Lips roundish, papillose. Maxillary barbel present. Teeth slender, bifid, with larger medial cusp bladelike and slightly rounded, and smaller lateral cusp minute and pointed.

Color in alcohol. Background color of dorsal surface of head and body dark gray to brown. Body, in larger specimens, completely covered by white spots, ranging in shape from vermiculated to ovoid and often coalescing with each other. Smaller specimens more regular gray to brown overall color pattern. On head, dark pigmentation more concentrated between nares, and along lateral head margin. On body, dark pigmentation concentrated at lateral regions. Ventral surface of body mostly unpigmented, with small scattered spots, which are more concentrated around oral disk and pectoralfin insertion.

Unbranched rays of dorsal, pectoral, pelvic and anal fins with five to seven, five to eight, two to five, and four to six dark transverse stripes, respectively. Branched rays of each of these fins with series of spots aligned in continuous transverse stripes. Caudal-fin coloration variable, with pattern ranging from striped along whole fin, to single large spot on fin base and scattered chromatophores distally. Ventral lobe of caudal fin usually more heavily pigmented than dorsal lobe.

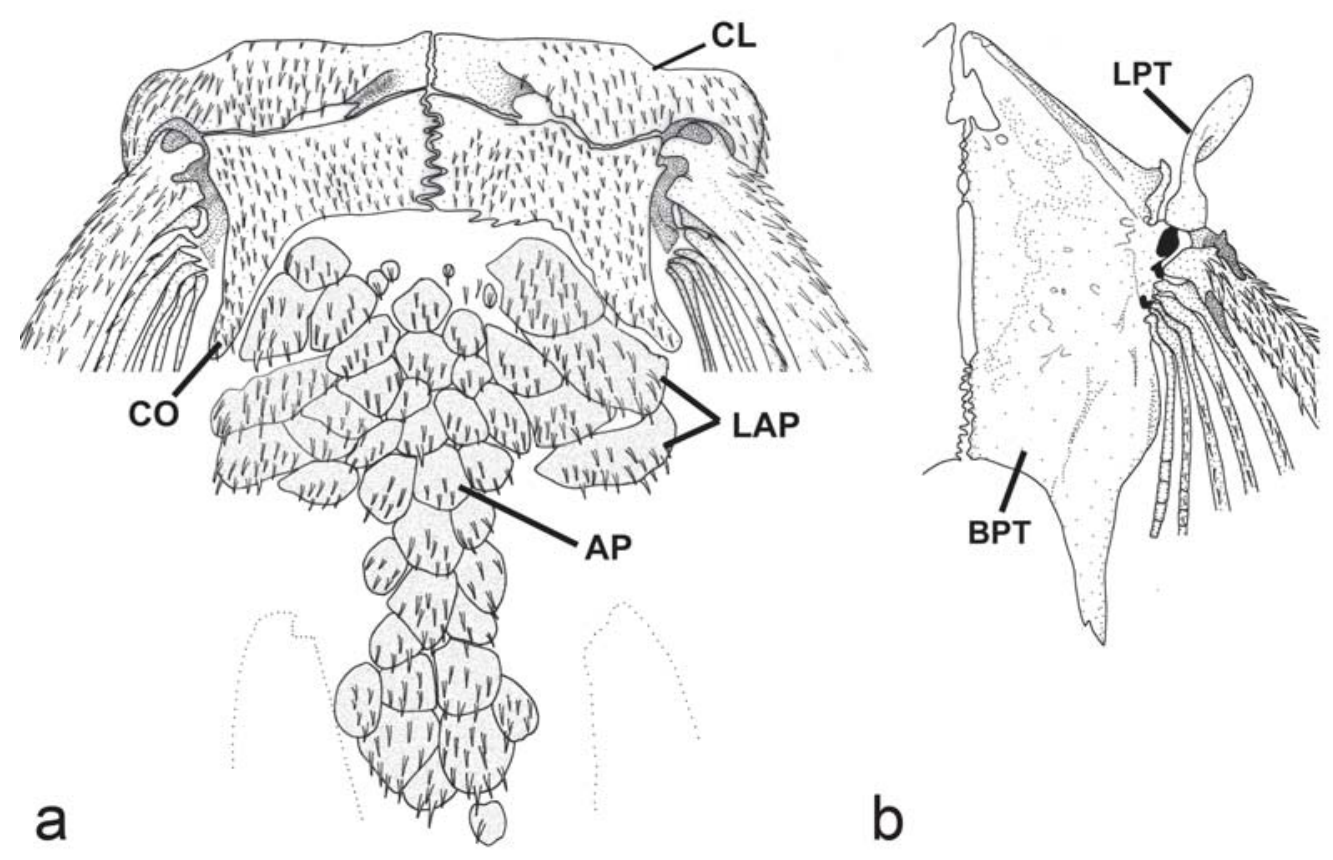

Fig. 4. Otothyropsis marapoama, paratype, LIRP 5641, $29.0 \mathrm{~mm}$ SL, a) pectoral girdle and abdominal platelets in ventral view, anterior to top; b) basipterygium in dorsal view, anterior to top. 


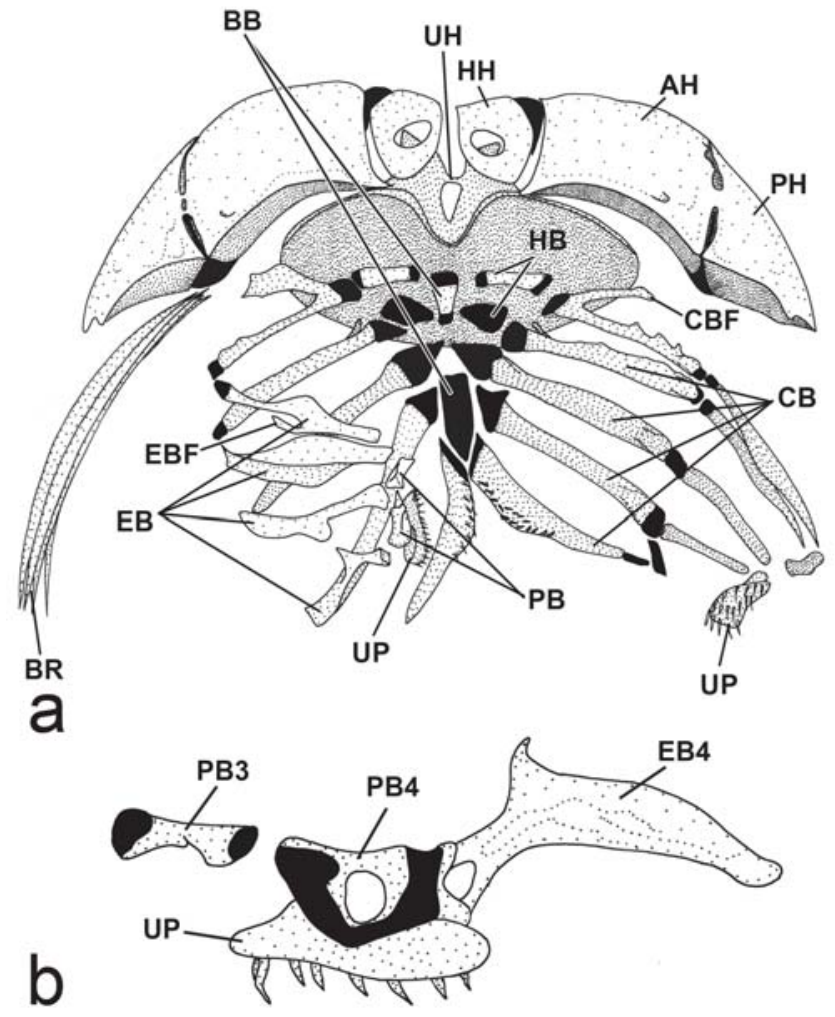

Fig. 5. Otothyropsis marapoama, a) branchial skeleton in dorsal view, except for upper elements of right side in ventral view, anterior to top, paratype, LIRP 5641, 24.2.mm SL; b) Upper pharyngeal toothplate in lateral view, showing its reduced condition relative to fourth infra-pharyngobranchial, Anterior to left paratype LIRP 4621, 27.6 mm SL (see Schaefer, 1991, fig. 5 a, b and c for comparisons).

Distribution. Known from two nearby localities in the same stream along the middle stretch of the rio Tietê, a tributary of the rio Paraná of southeastern Brazil (Fig. 2).
Etymology. The specific epithet marapoama is in reference to the county of the city in which the new species was collected. It is treated as a noun in apposition.

\section{Discussion}

In the phylogenetic scheme proposed by Schaefer (1998), Pseudotothyris and Otothyris form a clade which is the sister group of Schizolecis. The clade encompassing all three genera was supported by three synapomorphies, one of which is also present in the new species: upper pharyngeal tooth plate reduced (state 1 of character 23) (Fig. 5) (see Schaefer, 1991, figs. 5a, 5b and 5c for comparisons). The two other synapomorphies proposed by Schaefer (1998) [mesethmoid without pointed, arrow-shaped anterior margin (state 0 of character 3), and first dorsal-fin spinelet absent (state 2 of character 27)] were not considered synapomorphies after including Otothyropsis in our reanalysis. In Otothyropsis, the anterior margin of the mesethmoid is pointed with a ventral uncinate process (Fig. 6) (the plesiomorphic condition of character 3), and the dorsal-fin spinelet is reduced, but still present (state 1 of character 27). However, we found an additional synapomorphy for this clade including Otothyropsis. The enlarged pterotic fenestrae, typical of most hypoptopomatines, has a consistent pattern in Schizolecis, Otothyropsis, Pseudotothyris and Otothyris. In other Hypoptopomatinae with enlarged fenestrae, these are irregular in both size and shape, with the fenestrae expanded as large, cavernous grooves toward the ventral pterotic margin, while more dorsally located fenestrae have a more circular shape (Schaefer, 1998). The pterotic fenestrae in the clade (Schizolecis, (Otothyropsis, (Pseudotothyris, Otothyris))), however, are not irregularly arranged. We identified four enlarged fenestrae that are consistently found in all these genera (Fig. 7). Homologies are clearly identified based on the relative position of each fenestra in the pterotic and by landmarks, such as sensory canals. We defined and coded this character as state 1: presence of three distinct enlarged fenestrae at the ventral margin of pterotic (Fig. 7; fenestrae 1,2 and

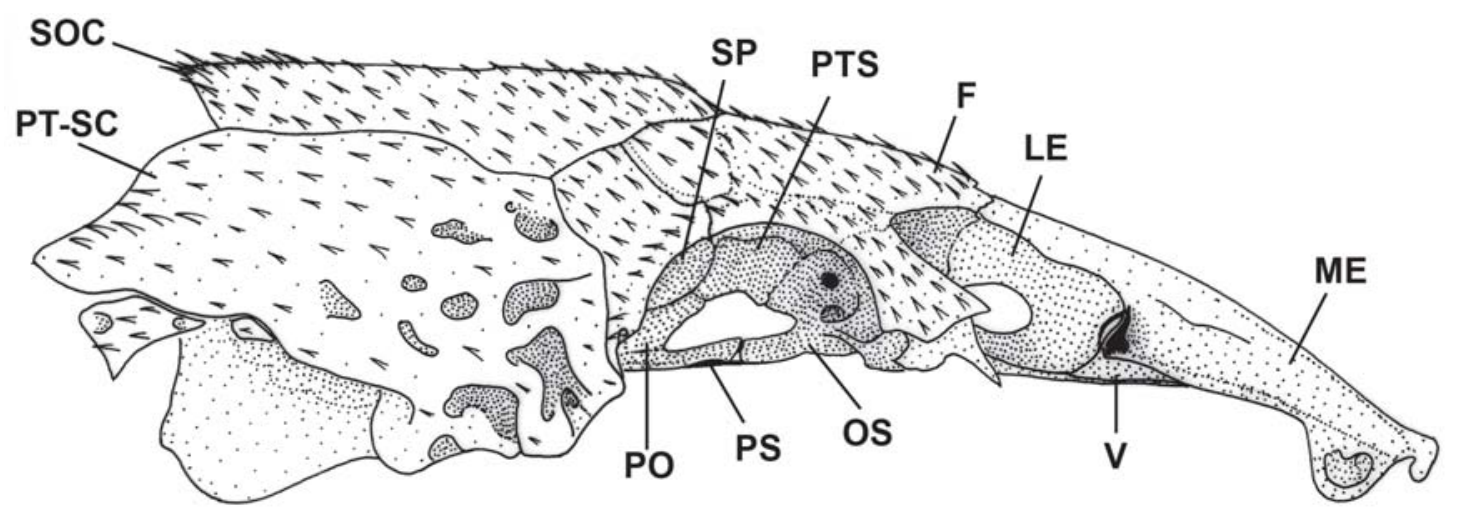

Fig. 6. Skull of Otothyropsis marapoama, paratype LIRP 5641, $29.0 \mathrm{~mm}$ SL, in lateral view. Dermal plates of the dorsal snout anterior to the frontals removed. Anterior to right. 
Table 2. Frequency distribution and summary of meristics for Otothyropsis marapoama. Plate counts were made in 8 specimens stained with alizarin red solution. Holotype values are marked with an asterisk. Meristics marked with double asterisks were counted in c\&s specimens only.

\begin{tabular}{|c|c|c|c|}
\hline Character & Frequency Distribution & Range & Mode \\
\hline Dorsal plates & $19(3)^{*} ; 18(5)$ & $18-19$ & 18 \\
\hline Mid-dorsal plates & $8(2) ; 10(2) ; 12(1)^{*} ; 13(1) ; 14(1) ; 16(1)$ & $8-16$ & 8 \\
\hline Median plates & $17(2) ; 18(1)^{*} ; 19(3) ; 20(1) ; 21(1)$ & $17-21$ & 19 \\
\hline anterior field plates & $3(3)^{*} ; 4(5)$ & $3-4$ & 4 \\
\hline gap field plates & $3(1) ; 4(1) ; 5(1) * ; 7(3) ; 9(2)$ & $3-9$ & 7 \\
\hline posterior field plates & $4(2) ; 5(3) ; 7(1) * ; 8(1) 9(1)$ & $4-9$ & 5 \\
\hline Mid-ventral plates & $14(1) ; 15(6)^{*} ; 16(1)$ & $14-16$ & 15 \\
\hline Ventral plates & $16(2) ; 17(3)^{*} ; 18(3)$ & $16-18$ & 18 \\
\hline Lateral abdominal plates & $2(4) ; 3(4) *$ & $2-3$ & 2 \\
\hline Predorsal plates & $3(8)$ & --- & --- \\
\hline Dorsal plates below dorsal-fin base & $5(3) ; 6(3) * ; 7(2)$ & $5-7$ & 5 \\
\hline Dorsal plates between end of dorsal base and caudal-fin membrane & $11(1) ; 12(3) ; 13(3) * ; 14(1)$ & $11-14$ & 13 \\
\hline Dorsal median unpaired plates & --- & --- & --- \\
\hline Ventral plates above anal-fin base & $3(8)$ & --- & --- \\
\hline Ventral plates between end of anal base and caudal-fin membrane & $9(6) * ; 10(2)$ & $9-10$ & 9 \\
\hline Dorsal-fin branched rays & 7 (all specimens) & --- & --- \\
\hline Pectoral-fin branched rays & 6 (all specimens) & --- & --- \\
\hline Pelvic-fin branched rays & 5 (all specimens) & --- & --- \\
\hline Anal-fin branched rays & 5 (all specimens) & --- & --- \\
\hline Caudal-fin branched rays & 14 (all specimens) & --- & --- \\
\hline Dorsal procurrent rays $* *$ & $26(1) ; 27(1) ; 28(1)$ & $26-28$ & --- \\
\hline Ventral procurrent rays $* *$ & $3(1) ; 4(2)$ & $3-4$ & 4 \\
\hline Total vertebrae $* *$ & $3(3)$ & $3-3$ & 3 \\
\hline Premaxillary teeth & $10(1) ; 12(1) ; 13(2) ; 14(1) ; 15(1) ; 16(1) ; 17(3) ; 18(4)^{*} ; 19(1)$ & $10-19$ & 18 \\
\hline Dentary teeth & $10(1) ; 11(3) ; 12(2) ; 15(3) ; 16(4) * ; 17(2)$ & $10-17$ & 16 \\
\hline
\end{tabular}

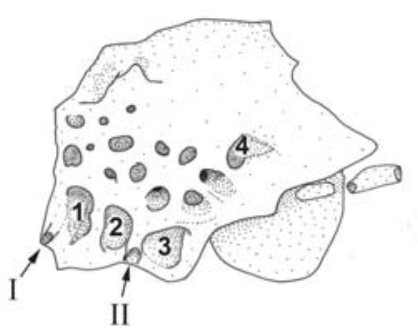

a

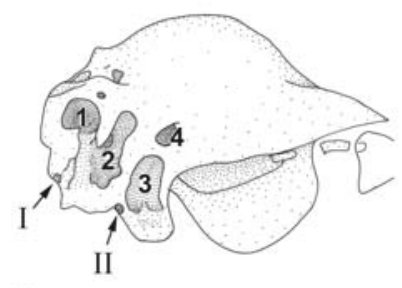

C

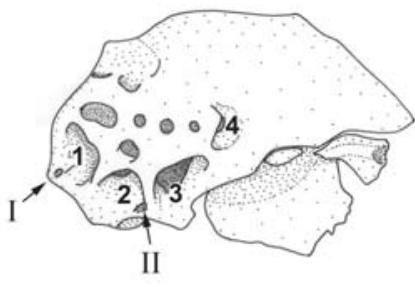

b

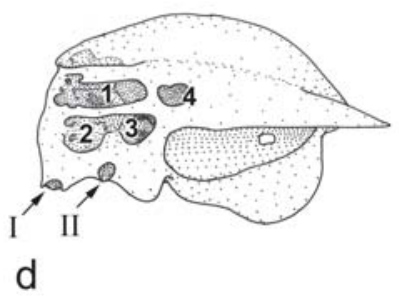

Fig. 7. Comparative morphology of the compound pteroticsupracleithrum-posttemporal, a) Schizolecis guntheri, LIRP $555,38 \mathrm{~mm}$ SL; , b) Otothyropsis marapoama, Paratype LIRP 5641, $29.0 \mathrm{~mm}$ SL, c) Pseudotothyris obtusa, LIRP 525, 27.4 $\mathrm{mm}$ SL, and d) Otothyris lophophanes, MZUSP 80205, $22 \mathrm{~mm}$ SL. Numbers 1 to 4 correspond to homologous fenestrae. Arrows indicate the homologous pores of the lateral line system. (I) opening of the preopercular latero-sensory canal and (II) opening of the posterolateral latero-sensory canal.

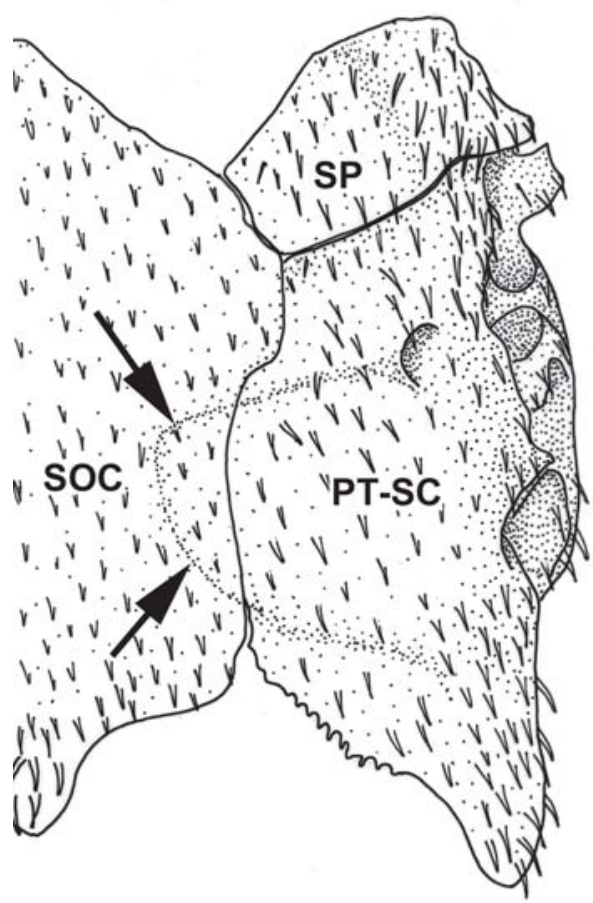

Fig. 8. Dorsal view of the posterolateral portions of the skull of Otothyropsis marapoama, Paratype, LIRP 5641, $29.0 \mathrm{~mm}$ SL. Arrows indicate the internal limits of the swimbladder capsule seen by transparency in c\&s specimens. Note that supraoccipital contributes to dorsal wall of swimbladder capsule. Anterior at top. 


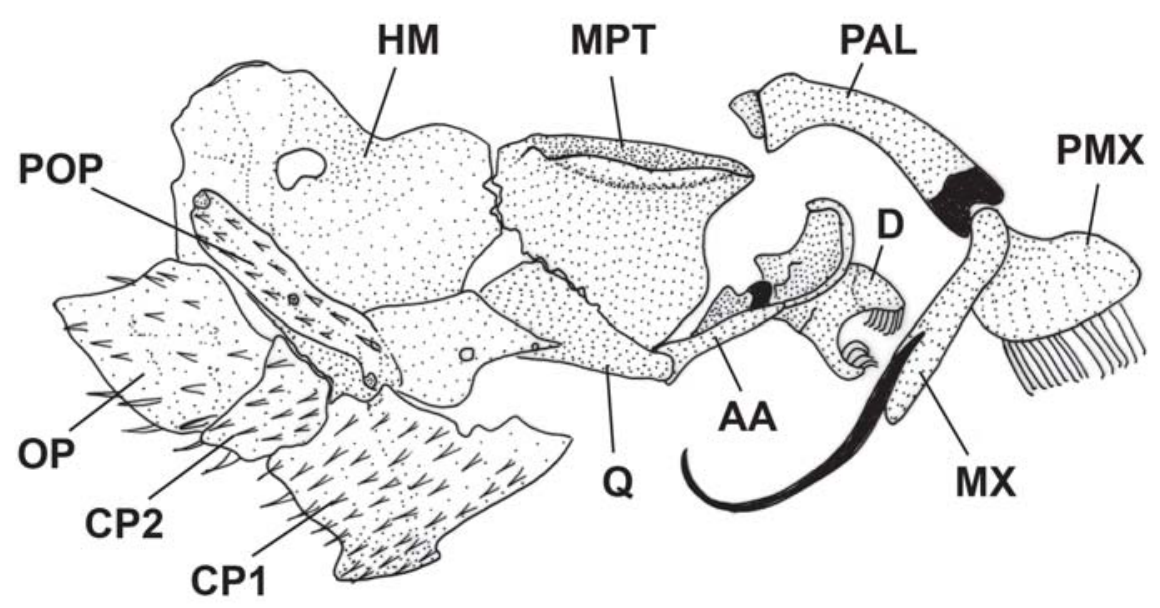

Fig. 9. Suspensorium of Otothyropsis marapoama. Paratype, LIRP 5641, 29.0 mm SL.

3) (present in Schizolecis and Otothyropsis), and state 2: the same fenestrae present, but continuous to each other in different degrees (present in Pseudotothyris and Otothyris). Other genera of Hypoptopomatine have a larger number of fenestrae at the ventral pterotic margin compared with the clade (Otothyropsis, (Pseudotothyris (Otothyris))) (see Schaefer, 1991, fig. 2).

The monophyly of Pseudotothyris + Otothyris is supported by three synapomorphies, also present in our new

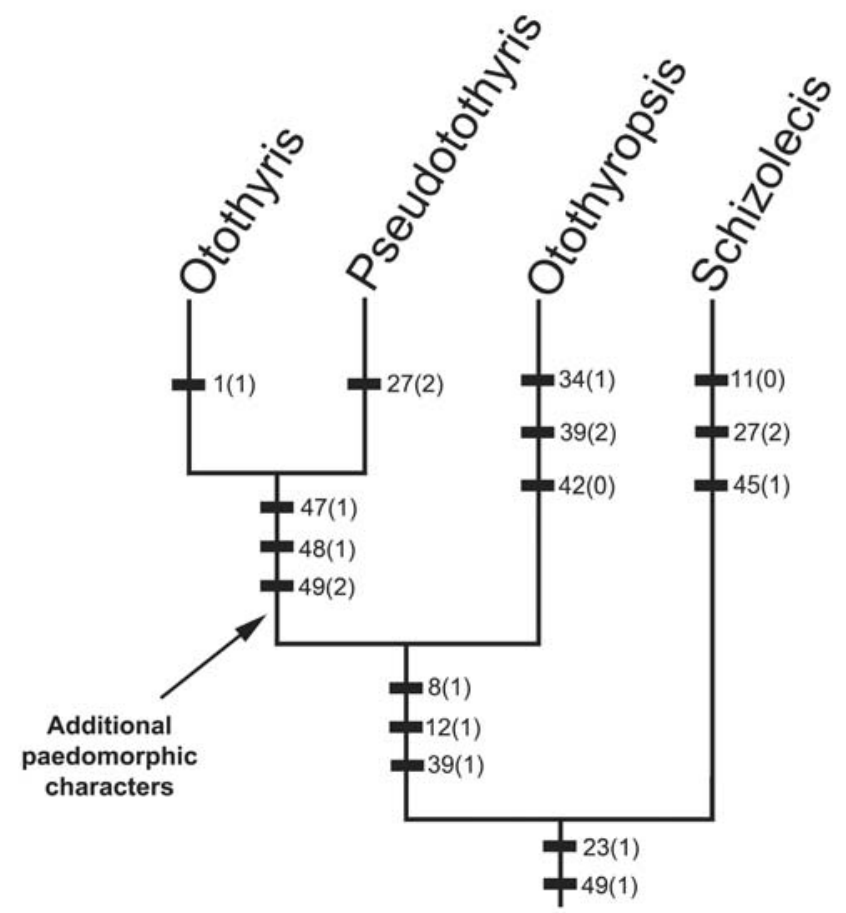

Fig. 10. Phylogenetic relationships of Otothyropsis marapoama. Characters states supporting nodes are unambiguous characters published by Schaefer (1998), except for characters 47, 48 and 49, included in our reanalysis. Paedomorphic characters commented in the text represent putative additional synapomorphies of Otothyris and Pseudotothyris. species: the presence of a pterotic posterolateral extension, which forms the dorsal margin of an enlarged lateral opening of the swimbladder capsule (Fig. 6); the supraoccipital forming the dorsal wall of the swimbladder capsule (Fig. 8); and presence of enlarged snout odontodes (Fig. 3). These characters correspond, respectively, to derived conditions of characters 8, 12, and 39 of Schaefer's (1998) phylogeny.

The inclusion of our new species in the phylogenetic framework of Schaefer (1998) and repeating the analysis with the original data set resulted in a single tree of 109 steps in length $(\mathrm{CI}=0.51$ and $\mathrm{RI}=0.71)$ corroborating the inclusion of the new genus in the clade that included Schizolecis, Pseudotothyris and Otothyris. In this first analysis, however, the new taxon appears to be the sister-group of Pseudotothyris due to the absence in both genera of a subopercular plate between the opercle and the canal-bearing plate at the ventrolateral margin of the check (Figs. 3 and 9). According to Schaefer (1998), this character is derived among the Hypoptopomatinae (derived condition of character 17).

Schaefer's (1998) analysis, however, did not include a distinctive sculpturing of the supraoccipital bone, that bears enlarged odontodes forming three conspicuous ridges or crests, which was first noted by Garavello et al. (1998) as shared by Otothyris and Pseudotothyris. We also observed that Otothyris and Pseudotothyris share the presence of enlarged odontodes forming conspicuous crests in the pre-nasal plates. We included these characters in Schaefer's (1998) original database (numbered as Characters 48 and 49, respectively) along with the characteristic pterotic fenestrae mentioned above (included as character 47) and obtained a single tree with 114 steps in length $(\mathrm{CI}=0.52$ and $\mathrm{RI}=0.71)$. In our reanalysis, therefore, Otothyropsis is the sister-group of Otothyris plus Pseudotothyris.

The presence of several paedomorphic characters suggests that Pseudothothyris and Otothyris are indeed more closely related to each other. Generally, immature individuals of Hypoptopomatinae exhibit salient crests of enlarged odontodes on the posterodorsal region of the supraoccipital 
Table 3. Character states of Otothyropsis marapoama, for 46 characters presented by Schaefer (1998) plus three additional characters included in the reanalysis $(47,48$, and 49) (see text for explanation). Characters are listed from top to bottom, arranged in separate groups in columns.

\begin{tabular}{cccccc}
\hline Characters & $1-10$ & $11-20$ & $21-30$ & $31-40$ & $41-49$ \\
\hline & 0 & 1 & 0 & 1 & 0 \\
& 0 & 1 & 0 & 0 & 0 \\
& 1 & 2 & 1 & 0 & $?$ \\
& 0 & 0 & 0 & 1 & 0 \\
Character states & 1 & 0 & 0 & 0 & $?$ \\
& 0 & 0 & 0 & 0 & 0 \\
& 0 & 1 & 1 & 1 & 1 \\
& 1 & 1 & 0 & 0 & 0 \\
& 0 & 0 & 0 & 2 & 0 \\
& 1 & 0 & 1 & 0 & \\
\hline
\end{tabular}

and pterotic-supracleithum (Garavello et al., 1998). In Otothyris and Pseudothothyris these odontode crests are retained in adults. In juveniles of Otothyropsis the crests are evident but disappear almost completely in larger specimens.

In Otothyris and Pseudothothyris, the dorsal portion of the swimbladder capsule, including both pteroticsupraclethrum and supraoccipital bones, are greatly arched forming a dome-like structure (Fig.7c and d). In the new genus, this character is only present in juveniles, suggesting that retention of this shape in Otothyris and Pseudothothyris might be paedomorphic and derived.

We also observed that in juveniles of Otothyropsis marapoama the prenasal plates consist of several minor plates that become gradually fused in larger specimens. In Otothyris and Pseudothothyris prenasal plates remain separate. The presence of several prenasal plates in adults seems to be another derived paedomorphic character shared by Otothyris and Pseudothothyris.

Another character that is apparently derived and paedomorphic in Otothyris and Pseudothothyris is the pattern of abdominal plates. Commonly, young loricariids have no platelets on the abdomen which becomes gradually plated during ontogeny. This is the case of Otothyropsis, in which juveniles possess naked abdomens that are almost completed plated in larger specimens (Fig. 4a). Otothyris and Pseudothothyris, however, possess abdomens with large naked areas and with only well-developed lateral plates. In Otothyropsis, lateral plates develop before the remaining abdominal plates. Other Hypoptopomatine have different degrees of naked abdomens. However, because Otothyropsis has a completely plated abdomen, allied with the fact that the lateral abdominal plates develop earlier than the remaining abdominal plates, we suggest that the presence of solely lateral plates in the abdomen of Otothyris and Pseudothothyris might be paedomorphic.

The several reductive features shared by Otothyris and Pseudotothyris, despite of being homoplastic and widespread in the Hypopotopomatinae, are likely to correspond to additional synapomorphies of both genera. The relative small size of Pseudotothyris and Otothyris and the phylogenetic retention of several juvenile characters also found in juveniles of
Otohyropsis marapoama, their putative sister-group, suggest a paedomorphic evolutionary origin. The generalized juvenile shape of these genera is suggestive of progenesis.

According to the evidence mentioned above, we conclude that Otothyropsis marapoama is more closely related to Pseudotothyris and Otothyris (Fig. 10). A detailed ontogenetic description of Otothyropsis and Schizolecis can be crucial for understanding the degree of sensorial specialization acquired by this clade, as well for providing additional information on miniaturization within Ostariophysi, an important phenomenon, as mentioned by Weitzman \& Vari (1988).

Comparative material. Otothyris lophophanes: MZUSP 80205, 7 (2 c\&s), Brazil, Rio de Janeiro, Silva Jardim, tributary of Rio São João, (22³4'00' 'S 42³3'59' 'W). Pseudotothyris janeirensis: MNRJ 4707, 20 (1 c\&s), Paratyes, Brazil, Rio de Janeiro, Município de Engenheiro Paulo de Frontin, rio dos Macacos, Represa Engenho da Serra, (approx. 2233'S 4340’W). Pseutotothyris obtusa: LIRP 525, 73 (2 c\&s), Brazil, São Paulo, Município de Cananéia (2456'S 47058"W). Schizolecis guntheri: LIRP 555, 601 (2 c\&s), Brazil, Rio de Janeiro, Município de Parati, Fazenda Muricana, rio Pedra Branca, (approx. $\left.23^{\circ} 10^{\prime} \mathrm{S} 44^{\circ} 48^{\prime} \mathrm{W}\right)$. Parotocinclus prata: LIRP 1136, 38 (2 c\&s), Paratypes, Brazil, Minas Gerais, Município de Presidente Olegário, headwaters of rio da Prata, ribeirão Quiricó, near Galena, São Francisco Basin (approx. 18¹9'S 4603 W). Hisonotus insperatus: LIRP 383, 11 (2 c\&s), Brazil, São Paulo, Município de Ribeirão Preto, rio Pardo, Paraná Basin, (approx. $\left.21^{\circ} 10^{\prime} \mathrm{S} 47^{\circ} 48^{\prime} \mathrm{W}\right)$. Hisonotus sp: LIRP 1580 , 12 (2 c\&s), Brazil, São Paulo, Municípo de Teodoro Sampaio, córrego São Carlos at Parque Estadual Morro do Diabo, Paraná $\operatorname{Basin}\left(22^{\circ} 35^{\prime} 28^{\prime \prime S ~ 52} 14^{\prime} 38^{\prime \prime} \mathrm{W}\right)$.

\section{Acknowledgments}

Roberto E. Reis (MCP), Pablo Lehmann (MCP), and Flávio C. T. Lima (MZUSP) provided important suggestions and criticism for the improvement of the manuscript. Marcelo R. de Carvalho provided detailed review of our English and other useful comments concerning manuscript contents. Guilherme C. Ribeiro helped with the computational cladistic analysis and provided other useful comments. We thank Mário C. C. Pinna (MZUSP), Osvaldo T. Oyakawa (MZUSP), Roberto E. Reis (MCP), Paulo A. Buckup (MNRJ) and Gustavo W. Nunan (MNRJ) for loans of specimens. Adriana K. Takako helped us in the field trip. This paper was financially supported by the “All Catfishes Species Inventory" Project (NSF DEB 0315963) that provides funding for field trips and visit to collections. We thank the Instituto Brasileiro do Meio Ambiente e Recursos Naturais Renováveis (IBAMA) for the collecting license (authorization no. 90/04, proc. no 02001.004137/2004-91). We also would like to thank our respective grants for financial support that allowed us to work on this project: Conselho Nacional de Desenvolvimento Científico e Tecnológico (CNPq 140488/04-9 to ACR) and Fundação de Amparo a Pesquisa do Estado de São Paulo (FAPESP 03/04397-0 to MC). 


\section{Literature Cited}

Armbruster, J. W. \& L. M. Page. 1996. Redescription of Aphanotorulus (Teleostei: Loricariidae) with description of one new species, A. ammophilus, from the Río Orinoco basin. Copeia, 1996 (2):379-389.

Bockmann, F. A. \& A. C. Ribeiro. 2003. Description of a new suckermouth armored catfish of the genus Pareiorhina (Siluriformes: Loricariidae), from southeastern Brazil. Ichthyological Exploration of Freshwaters, 14(3): 231-242.

Boeseman, M. 1968. The genus Hypostomus Lacépède, 1803, and its Surinam representatives (Siluriformes, Loricariidae). Zoologische Verhandelingen, 99:1-89.

Britski, H. A. \& J. C. Garavello. 1984. Two new southeastern Brazilian genera of Hypoptopomatinae and a redescription of Pseudotocinclus Nichols, 1919 (Ostariophysi, Loricariidae). Papéis Avulsos de Zoologia, 35(21): 225-241.

Garavello, J. C., H. A. Britski \& S. A. Schaefer. 1998. Systematics of the genus Otothyris Myers 1927, with comments on geographic distribution (Siluriformes: Loricariidae: Hypoptopomatinae). American Museum Novitates, 3222: 1-19.

Lundberg, J. G. \& J. N. Baskin. 1969. The caudal skeleton of the catfishes, order Siluriformes. American Museum Novitates, 2398: 1-49.

Myers, G. S. 1927. Descriptions of new South American freshwater fishes collected by Dr. Carl Ternetz. Bulletin of the Museum of Comparative Zoology, 68 (3): 107-135.

Schaefer, S. A. 1991. Phylogenetic analysis of the loricariid subfamily Hypoptopomatinae (Pisces: Siluroidei: Loricariidae), with comments on generic diagnoses and geographic distribution. Zoological Journal of the Linnean Society, 102:1-41.
Schaefer, S. A. 1997. The Neotropical Cascudinhos: Systematics and biogeography of the Otocinclus catfishes (Siluriformes: Loricariidae). Proceedings of the Academy of Natural Sciences of Philadelphia, 148:1-120.

Schaefer, S. A. 1998. Conflict and resolution: Impact of new taxa on phylogenetic studies of the neotropical cascudinhos (Siluriformes: Loricariidae). Pp. 375-400 In: L. R. Malabarba, R. E. Reis, R. P. Vari, C. A. S. Lucena \& Z. M. S. Lucena (Eds.). Phylogeny and Classification of Neotropical Fishes. Edipucrs, Porto Alegre. 603p.

Schaefer, S. A. 2003. Loricariidae - Hypoptopomatinae (Armored catfishes). Pp. 321-329 In: R. E. Reis, S. O. Kullander \& C. J. Ferraris, Jr. (Eds.) Checklist of the Freshwater Fishes of South and Central America. Edipucrs, Porto Alegre. 729p.

Swofford, D. L. 1993. PAUP: Phylogenetic Analysis Using Parsimony, Version 3.1.1. Washington, D.C.: Smithsonian Institution.

Taylor, W. R. \& G. C. Van Dyke. 1985. Revised procedures for staining and clearing small fishes and other vertebrates for bone and cartilage study. Cybium, 9(2): 107-119.

Weitzman, S. H. \& R. P. Vari. 1988. Miniaturization in South American freshwater fishes: and overview and discussion. Proceedings of the Biological Society of Washington, 101(2): 444-465.

Received July 2005 Accepted October 2005 